University of Montana

ScholarWorks at University of Montana

8-2001

\title{
Restoring Enriched Grasslands: Effects of Mowing on Species Richness, Productivity, and Nitrogen Retention
}

John L. Maron

University of Montana - Missoula, john.maron@mso.umt.edu

Robert L. Jefferies

University of Toronto

Follow this and additional works at: https://scholarworks.umt.edu/biosci_pubs

Part of the Biology Commons

Let us know how access to this document benefits you.

\section{Recommended Citation}

Maron, John L. and Jefferies, Robert L., "Restoring Enriched Grasslands: Effects of Mowing on Species Richness, Productivity, and Nitrogen Retention" (2001). Biological Sciences Faculty Publications. 344. https://scholarworks.umt.edu/biosci_pubs/344

This Article is brought to you for free and open access by the Biological Sciences at ScholarWorks at University of Montana. It has been accepted for inclusion in Biological Sciences Faculty Publications by an authorized administrator of ScholarWorks at University of Montana. For more information, please contact scholarworks@mso.umt.edu. 


\title{
RESTORING ENRICHED GRASSLANDS: EFFECTS OF MOWING ON SPECIES RICHNESS, PRODUCTIVITY, AND NITROGEN RETENTION
}

\author{
JOHN L. MARON ${ }^{1,3}$ AND Robert L. JEFFERIES ${ }^{2}$ \\ ${ }^{1}$ Department of Botany, Box 355325, University of Washington, Seattle, Washington 98195 USA \\ ${ }^{2}$ Department of Botany, University of Toronto, 25 Willcocks Street, Toronto, Ontario, Canada M5S $3 B 2$
}

\begin{abstract}
Species-rich grasslands that become enriched with nitrogen often suffer decreases in species richness, increases in plant biomass, and invasion by weedy exotic species. Suitable techniques to restore enriched grasslands and reestablish native communities are increasingly needed. Here we report results of a 5-yr experiment in enriched coastal prairie grasslands (Bodega Marine Reserve, Bodega Bay, California, USA), to determine the combined effects of mowing and biomass removal on total soil nitrogen, net rates of mineralization, nitrogen retention, and species richness and biomass. We mowed and removed plant biomass from plots in areas where the N-fixing shrub, bush lupine (Lupinus arboreus), had greatly enriched the soil, and where the community was composed of weedy introduced plants. Our goal was to facilitate the establishment of the native grassland assemblage such as was found at nearby low soil nitrogen sites.

Mowing and biomass removal resulted in a dramatic change in the species assemblage, from exotic annual grasses to a mixed exotic/native forb community composed primarily of perennials. Species richness was significantly greater in treated plots than in control plots; weedy exotic grasses diminished in abundance, and both native and exotic forb species increased. In mowed vs. control plots, there was significantly less mean aboveground biomass, but significantly greater belowground biomass. This shift in species composition had significant impacts on nitrogen retention. In late fall and winter when plant-available $\mathrm{N}$ was highest, much nitrogen leached from the effectively fallow control plots where germination of annual grasses did not peak until midwinter. In contrast, mowed plots retained substantially greater amounts of nitrogen, due to the presence of perennial plants possessing large amounts of belowground biomass early in the season. Despite the cumulative removal of $22 \mathrm{~g} \mathrm{~N} / \mathrm{m}^{2}$ in biomass over $5 \mathrm{yr}$, there was no difference between mowed and control plots in total soil $\mathrm{N}$, pool sizes of inorganic $\mathrm{N}$, or net rates of $\mathrm{N}$ mineralization. The results indicate that removal of plant biomass by mowing shifted this plant community from an annual grass to a perennial forb assemblage. However, in doing so, $\mathrm{N}$ retention by vegetation was increased, making it more difficult to reduce soil $\mathrm{N}$.
\end{abstract}

Key words: grassland restoration; invasion; mowing; nitrogen retention; soil nitrogen dynamics; species richness.

\section{INTRODUCTION}

Nitrogen enrichment of natural communities is a growing conservation problem (Vitousek et al. 1997, Bakker and Berendse 1999). Increasingly, oxides of nitrogen are added to the atmosphere as a result of the fossil fuel burning and intensive agricultural activities (Galloway et al. 1994). These inorganic forms of nitrogen are redistributed through the atmosphere, and ultimately are deposited in natural communities where they may trigger changes in community composition and ecosystem processes (Vitousek et al. 1997). In addition, invasive nitrogen-fixing species are increasing in abundance in many areas. Due to their ability to greatly increase total soil nitrogen and alter soil-nitrogen dynamics, these species can also have detrimental effects on communities and ecosystems (Vitousek and

Manuscript received 29 November 1999; revised 31 May 2000; accepted 12 June 2000.

${ }^{3}$ E-mail: jmaron@u.washington.edu
Walker 1989, Witkowski 1991, Stock and Allsopp 1992, Stock et al. 1995). Regardless of the cause, in many systems nitrogen enrichment increases plant productivity and reduces species diversity (Bobbink and Willems 1987, Aerts and Berendse 1988, Bobbink 1991, Hobbs and Huenneke 1992, Marrs 1993, Wedin and Tilman 1996, Foster and Gross 1998). Nitrogen enrichment also facilitates the spread of invasive species. These species often outcompete the slower growing native species that thrive under low-N conditions (Huenneke et al. 1990, Hobbs and Huenneke 1992, Milchunas et al. 1995, Burke and Grime 1996, Wedin and Tilman 1996, Maron and Jefferies 1999, Stohlgren et al. 1999). In some habitats of northern Europe, critical loads for nitrogen have been exceeded. Plant assemblages are changing as slower growing species are outcompeted by plants that grow rapidly under conditions of high nitrogen (Bakker and Berendse 1999).

Restoration of nitrogen-enriched sites heavily invaded by exotic species is an ongoing conservation 
challenge. One option is to try to reduce soil N, thereby shifting competitive interactions and facilitating the reestablishment of native plants that are better adapted to low soil nitrogen conditions. In addition to logistical challenges, a difficulty with this approach is that there are no clear predictions of how reducing $\mathrm{N}$ availability will affect species richness or other community attributes. Ironically, both theory and empirical work predict how species richness should respond to increasing soil N (Grime 1979, Marrs 1993). For grasslands, the relationship between available soil $\mathrm{N}$ and species richness is usually hump-shaped, with species richness peaking at some moderately low level of soil $\mathrm{N}$, and declining thereafter (Vermer and Berendse 1983, Tilman 1997, Foster and Gross 1998, Stohlgren et al. 1999). The mechanism responsible for declines in species richness on the downward side of the soil $\mathrm{N}$ vs. species richness curve is thought to be competitive dominance, which enables a few fast-growing nitrophilous species to overgrow and eliminate slower growing species where soil $\mathrm{N}$ is readily available (Grime 1979, Tilman 1988).

Whether or not reducing nitrogen in enriched communities leads to increased native plant diversity is an open question (Marrs 1993). Once a community is dominated by weedy species, it may be difficult to reestablish a more diverse flora, even when reductions in soil $\mathrm{N}$ occur (Marrs 1993). Reductions in soil $\mathrm{N}$ might have little impact on a plant community if propagules of many desired species are absent, or if competitive hierarchies do not change. Furthermore, there are often strong positive feedbacks between plants and biogeochemical processes (Wedin and Tilman 1990, Vinton and Burke 1997, Hooper and Vitousek 1998). In the well-studied case of prairie grasslands in the midwestern United States, enrichment of low-N sites leads to a switch in the plant community from native perennial $\mathrm{C}_{4}$ grasses to exotic perennial $\mathrm{C}_{3}$ grasses (Wedin and Tilman 1996). The $C: N$ ratio of these $C_{3}$ grasses is lower and the rates at which their litter decomposes is faster than that of the $\mathrm{C}_{4}$ species (Wedin and Tilman 1990). Sites composed of these different functional types of grasses may also differ in their nitrogen retention. This implies that it may be difficult to effectively reduce soil $\mathrm{N}$ without simultaneously altering plant-community composition. Whether or not this is the case for other types of prairie grassland systems is unclear.

Another technique used to restore species richness within enriched sites is managed grazing. Grazing can reduce the abundance of competitive dominants, thereby maintaining species richness despite nitrogen enrichment. For example, Collins et al. (1998) found that grazing (as simulated by mowing) maintained species richness even within plots that were enriched with nitrogen-conditions that would otherwise lead to the reduction of species richness. Similar experiments in Britain, using real grazers, have also shown that graz- ing can maintain species richness within enriched grasslands (Wilson et al. 1995).

Along portions of the California coast, the fast-growing N-fixing shrub bush lupine (Lupinus arboreus) enriches N-poor sandy soils with nitrogen. Grasslands where lupine populations have turned over for many years contain almost twice as much total and plantavailable soil nitrogen as nearby sites that lack bush lupine (Maron and Jefferies 1999). Lupines can grow at high densities in grasslands. While alive, they simultaneously enrich sites and shade the ground beneath them (Maron and Connors 1996, Maron and Jefferies 1999). When individuals or entire stands die, which is frequent (Strong et al. 1995), nitrogen enrichment of soil leads to a switch from a mostly perennial $\mathrm{C}_{3}$ grassland to an exotic annual $\mathrm{C}_{3}$ grassland (Maron and Jefferies 1999). Sites low in soil $\mathrm{N}$ and historically lacking lupine, contain a more diverse coastal prairie plant assemblage. This assemblage consists of native perennial grasses, as well as a mix of annual and perennial forbs, of which many are native (see Maron and Connors 1996 for a list of species). These patches of mostly native grassland have similar edaphic conditions, as do sites that support dense lupine populations (Maron and Jefferies 1999). Historical photographs indicate that previous agricultural use may have kept lupines from these areas, although these shrubs have been slowly encroaching. Along the Californian coast as a whole, native coastal prairie assemblages are increasingly rare; most coastal grasslands are dominated by nonnative species (Heady et al. 1995).

Here we report the results of a 5-yr experiment to determine if late-spring mowing and biomass removal can be used successfully as a restoration tool in enriched sites. The goal was to determine if mowing could increase native species richness within heavily invaded sites that were previously enriched by bush lupine. There are two routes by which mowing and biomass removal could accomplish this management objective. First, biomass removal can reduce the labile pool of soil $\mathrm{N}$, because nitrogen taken up by highly productive grasses is extracted each year (Rizand et al. 1989). However, since only a small fraction of the total soil organic pool of $\mathrm{N}$ is mineralized annually (Addiscott et al. 1991, Maron and Jefferies 1999), this approach may require many years to significantly reduce the pool of plant-available N (Jenkinson and Johnston 1977, Johnston and Poulton 1977). Second, mowing with biomass removal can simulate grazing (Collins et al. 1998) both by opening up sites for native plant regeneration, reducing the seed rain of dominant aliens, and by changing competitive interactions.

We compared soil-nitrogen dynamics and plant-community composition between mowed and unmowed plots within areas that had been enriched by lupine. At the start of the experiment, the sites were devoid of adult lupines, but over the five years of the experiment, some lupines established but rapidly died in control 
plots. To determine if mowing effectively reduced soil nitrogen, we compared total soil $\mathrm{N}$, exchangeable soil $\mathrm{N}$, rates of net $\mathrm{N}$ mineralization, and soil nitrogen retention and leaching, between mowed and control plots. To determine whether mowing reduced plant-available nitrogen, after mowing for $4 \mathrm{yr}$ we added $\mathrm{N}$ fertilizer to subplots within mowed plots, testing for evidence of N-limited plant growth. We examined the effects of mowing on the plant community by comparing total species richness and biomass between mowed and unmowed plots. We also added alien grass seeds to subplots within mowed plots, to determine if any reduction in alien annual grass abundance might be due to seed limitation brought on by annual mowing and biomass removal before seed dispersal.

\section{Methods}

This study took place on the 147-ha University of California Bodega Marine Reserve (BMR) located in Sonoma County, California, USA. The site experiences a mediterranean climate; winter rains are heaviest from November to March and summers are dry, but cool. The average annual rainfall for the site is $85.7 \mathrm{~cm}$. The coastal grassland community at BMR is principally composed of the annual grasses Lolium multiflorum and Bromus diandrus, with bush lupine interspersed within this matrix. However, embedded within these grasslands there are a few remnant patches of mostly native vegetation that have historically lacked lupine.

Dense even-aged stands of bush lupine establish within coastal grasslands from an abundant seed bank. Die-off of individuals and entire stands of plants is common due to heavy belowground insect herbivory (Strong et al. 1995, Maron 1998), flooding, and occasionally high densities of defoliating caterpillars that occur late in the season (Maron et al. 2001). After lupines die, bare N-rich soil under shrubs is rapidly colonized by weedy plants from the grassland matrix in which lupines are embedded. On a larger spatial scale, sites that have undergone repeated bouts of lupine establishment, stand development, and then dieoff, are composed almost entirely of these exotic grasses, along with a small number of native and exotic forbs. Although lupines ultimately recolonize sites where individuals have previously died, weedy grasses persist in the interstitial spaces between shrubs. In contrast, a few areas that have historically lacked lupine are low in soil $\mathrm{N}$. The plant community in these sites is more diverse, composed of perennial native grasses, native forbs (mostly annuals), and some exotic grasses and forbs (Maron and Connors 1996, Maron and Jefferies 1999). As discussed more fully in Maron and Jefferies (1999), other than the historical presence or absence of lupine (and the concomitant effects on soil $\mathrm{N}$ ), we have found no difference in the physical environment between sites dominated by exotic annual grasses and those adjacent sites, low in soil $\mathrm{N}$, that support a more native grassland community. In fact, since the cessation of agricultural activities on BMR over 35 yr ago, lupines have been slowly spreading into several of these mostly native sites.

\section{Experimental design}

In February 1993, we established two $4 \times 4$ m plots in each of six randomly selected locations within a large 1-1.5-ha area where lupines had died en masse the previous year. Individual plots were separated from each other by several meters, and replicate pairs of plots were separated by at least $20 \mathrm{~m}$. At each location, we randomly assigned a mowing and biomass removal treatment to one plot of each pair. Initial measurements of soil characteristics (percentage of sand, silt, and clay, and soil pH taken in February 1995) and amounts of instantaneous soil N taken in June 1994 and every month from September-April in 1994-1995, revealed that there were no significant initial differences between control and mowed plots in these soil variables (J. L. Maron and R. L. Jefferies, unpublished data). At the beginning of the experiment, all plots contained the dead skeletons of lupines that died the year before, but no other vegetation. Plots were devoid of vegetation because the dense stand of lupine that previously occupied sites shaded the soil beneath them, inhibiting plant establishment (Maron and Jefferies 1999). Lupine skeletons were removed in treatment plots but left in situ in control plots. Adult lupines reestablished in control plots in 1996, from seedlings that germinated in 1995. In 1997, these adults covered an average of 55\% of the area of control plots, before dying in 1998. The presence of adult lupines in control plots in 1996 and 1997 did not appear to dramatically influence species richness (see Results).

We mowed plots with a motorized bar mower in midMay of each year, at the seasonal peak of grass biomass when amounts of plant litter were low. Vegetation was cut within a few centimeters of the ground, bagged, and immediately weighed. We took subsamples from the cut vegetation and determined its wet and dry mass (after $48 \mathrm{~h}$ of drying at $60^{\circ} \mathrm{C}$ ) in order to calculate the dry biomass of the total clippings from each plot, expressed as grams per square meter. In control plots, we harvested vegetation within a haphazardly placed 30 $\times 30 \mathrm{~cm}$ quadrat, and estimated its dry biomass as above.

Each year between 1994 and 1997, we also analyzed a randomly selected subsample of vegetation from each mowed plot for total $\mathrm{N}$ and $\mathrm{C}$ content. Subsamples were dried, ground, and analyzed using a LECO 600 carbonhydrogen analyzer (LECO, St. Louis, Missouri, USA). We multiplied the percentage of $\mathrm{N}$ in the vegetation sampled from each plot by the total dry biomass in that plot, to determine the total amount of $\mathrm{N}$ removed annually by mowing.

Prior to mowing in mid-May 1998 and 1999, we sampled aboveground plant biomass in $30 \times 30 \mathrm{~cm}$ subplots, randomly placed in both unmowed and 
mowed plots. We clipped all aboveground vegetation and sorted it into grasses and forbs. These were weighed separately after drying for $48 \mathrm{~h}$ at $60^{\circ} \mathrm{C}$. To estimate the belowground forb biomass in mowed and control plots, we took $20 \times 20 \times 20 \mathrm{~cm}$ deep blocks of soil from a randomly chosen location. In the laboratory, we carefully washed roots free of soil, and separated forb roots. We could not use this technique to estimate belowground grass biomass, because fine grass roots were easily destroyed when masses of plants were washed together. Instead, from each plot we carefully extracted individual plants of the two dominant grasses, Bromus diandrus and Lolium multiflorum, with their entire shoot and root systems intact $(n=3-4$, from each plot). The shoots and roots from these plants were weighed separately. From these results we calculated the dry mass shoot:root ratio. Using this ratio, we estimated total belowground grass biomass, based on our estimates of the aboveground biomass of these grasses. Dried biomass samples of grasses and forbs from each plot were ground and analyzed for total $\mathrm{N}$ and $\mathrm{C}$ with a carbon-hydrogen analyzer. We compared the total above- and belowground biomass in control and mowed plots across both years, using a repeatedmeasures ANOVA with year as the repeated measure. For this and other comparisons between mowed and control plots, we opted not to perform a paired analysis (treating mowed and control plots from each location as a pair), because there was often as much heterogeneity at a local level as there was across locations. This and all other statistical analyses were performed using SYSTAT 8.0 (SYSTAT 1998).

Mowing could potentially reduce the abundance of exotic annual grasses via several mechanisms. These include lowering soil nitrogen, changing competitive interactions between natives and exotics, or removing exotic grass seed that otherwise that would have dispersed in plots. By eliminating litter, biomass removal might also reduce grass seedling establishment in subsequent winters (Foster and Gross 1998). To separate these possible effects, in the fall of 1997 we divided each mowed $4 \times 4 \mathrm{~m}$ plot into four $1.8 \times 1.8 \mathrm{~m}$ subplots with $0.4 \mathrm{~m}$ wide walkways separating subplots (Fig. $1)$.

To determine if nitrogen had been reduced in mowed plots to a level where it might limit the growth of vegetation, we compared the standing crop of vegetation in the presence or absence of urea amendments. Two additions of $32.3 \mathrm{~g}$ slow-release urea (38-0-0 urea formaldehyde; $3.5 \mathrm{~g} \mathrm{~N} / \mathrm{m}^{2}$ ) were added to a randomly selected subplot in each plot. We added an amount of urea to plots to more than compensate for the amount of nitrogen we had removed as a result of mowing. Urea was added initially to subplots on 17 November 1997 and again on 20 January 1998. On 14 May 1998, we harvested aboveground vegetation within a $30 \times$ $30 \mathrm{~cm}$ quadrat randomly placed in the treated and control subplots within mowed plots. Vegetation was cut

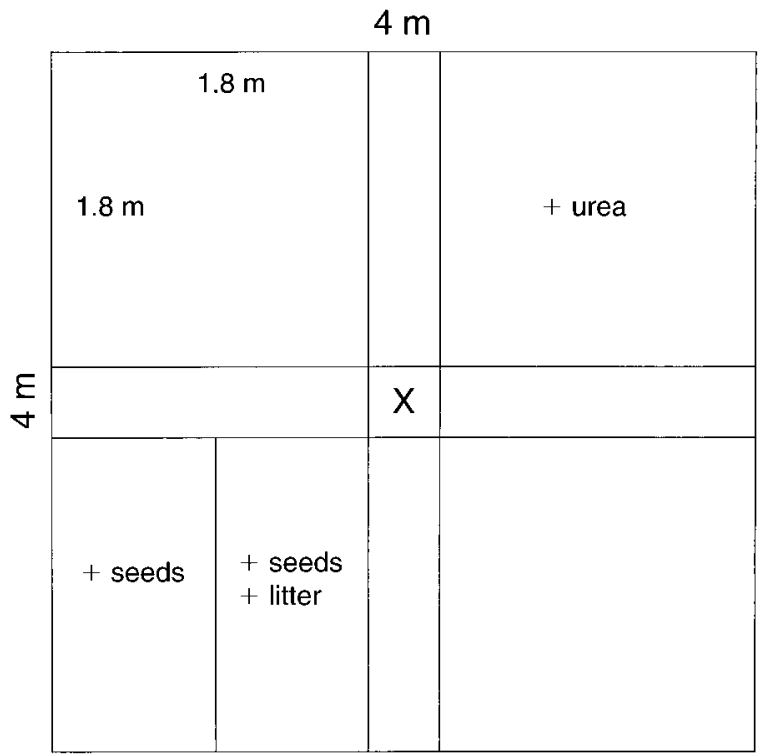

FIG. 1. Layout of mowed plots in 1998 and 1999. The parallel lines across the center of the plot indicate walkways (see Methods for details). Subplots where urea and seeds (and seeds plus litter) were added varied across replicate plots. $X$ $=$ location where each lysimeter was installed.

at ground level, bagged, dried at $60^{\circ} \mathrm{C}$ for $2 \mathrm{~d}$, and weighed. Using a $t$ test, we compared the total aboveground biomass in samples from urea-addition subplots and unmanipulated plots.

To examine if seed limitation or the lack of litter might limit grass recruitment in mowed plots, we randomly assigned one of the remaining three subplots to receive either seed of Bromus diandrus or seed plus litter (Fig. 1). Ripe seeds of B. diandrus, as well as senesced plants, were collected from the grasslands surrounding each plot in July. We divided this subplot in half. On 28 July 1998 we added $18 \mathrm{~g}$ of seeds to one randomly selected half of the subplot and added $18 \mathrm{~g}$ of seed covered with senesced grass litter (stripped clean of seeds) to the other half of the subplot. We covered this subplot (and control plots) with bird netting (2-cm mesh size; large enough to allow birds and rodents access to plots), staked to the ground so that litter and seeds would not be blown away. This netting was removed on 22 February 1999 after seeds started to germinate. On 3 May we counted the number of flowering culms of $B$. diandrus in each half of the subplot to which we added seeds or seeds plus litter. We also counted the number of flowering culms in half of a randomly chosen untreated subplot. We compared the number of flowering culms within different subplots with the use of a one-way ANOVA, and used a least squares mean post hoc comparison to examine specific differences between subplots.

\section{Species composition}

Each year in May from 1993 to 1997, we recorded the species composition of the vegetation in two per- 
manent $0.5 \times 0.5 \mathrm{~m}$ subplots within each $4 \times 4 \mathrm{~m}$ plot. Since mowed plots were subdivided into approximate quarters in the fall of 1997 (Fig. 1), only a $1.8 \times 1.8$ $\mathrm{m}$ control area remained unmanipulated. Therefore, we were only able to sample vegetation within one $0.5 \times$ $0.5 \mathrm{~m}$ quadrat randomly placed inside the $1.8 \times 1.8 \mathrm{~m}$ control subplot in mowed plots in 1998 and 1999. In control plots during these two years, we randomly chose one of the two permanent $0.5 \times 0.5 \mathrm{~m}$ subplots in which to sample species richness. Within the $0.5 \times$ $0.5 \mathrm{~m}$ subplots, we recorded shoot frequency of species within a grid of $2510 \times 10 \mathrm{~cm}$ squares. We calculated the average frequency for all grass species in 1998 and 1999 based on frequency values in the six plots. We used repeated-measures ANOVA to compare the total species richness (forbs and grasses combined) between mowed and control plots in 1998 and 1999, the last two years of the experiment.

\section{Total soil nitrogen and carbon}

To determine effects of mowing on total soil nitrogen and carbon, in mid-May of 1998 and 1999 we took 50 $\mathrm{g}$ of soil for $\mathrm{N}$ and $\mathrm{C}$ analysis from the center of each plot, between 5 and $10 \mathrm{~cm}$ below the soil surface. Soils were dried at $50^{\circ} \mathrm{C}$ for $10 \mathrm{~d}$ and total soil $\mathrm{N}$ and $\mathrm{C}$ were measured with a carbon-hydrogen analyzer. We used a $t$ test to compare total soil $\mathrm{N}$ values of mowed and control plots. We converted soil $\mathrm{N}$ and $\mathrm{C}$ values to a grams per square meter basis based on previous estimates of soil bulk density (Maron and Jefferies 1999).

\section{Exchangeable levels of inorganic soil nitrogen and net rates of nitrogen mineralization}

Instantaneous levels of soil $\mathrm{N}$ and net rates of nitrogen mineralization in mowed and control plots were measured each month, from 29 September 1997 to 29 May 1998 and from 2 October 1998 to 3 May 1999. Measurements were not taken during summer because mineralization rates during this dry period are extremely low (Maron and Jefferies 1999; J. L. Maron and R. L. Jeffries, unpublished data). Our methods for soil sampling, extraction, and analysis are identical to those explained elsewhere (Maron and Jefferies 1999). Each month we took two soil samples: one was used to determine exchangeable levels of soil $\mathrm{NH}_{4}{ }^{+}$and $\mathrm{NO}_{3}{ }^{-}$, and the other was incubated with a buried polyethylene bag in the field for 1 mo to determine net rates of $\mathrm{N}$ mineralization. Soil taken from the field was placed in $1 \mathrm{~mol} / \mathrm{L} \mathrm{KCl}$ for $24 \mathrm{~h}$ to extract exchangeable ammonium and nitrate ions. Soil moisture was estimated gravimetrically and used to correct for differences in moisture content between samples when calculating monthly net rates of nitrogen mineralization and instantaneous levels of exchangeable soil N.

We calculated monthly rates of net nitrogen mineralization by determining ammonium and nitrate levels in soil within buried bags after incubation, and subtracting from these values the amounts of ammonium and nitrate found in unbagged samples collected at the beginning of each incubation. These values were summed for each plot from September (1997) or October (1998) to April, and mean net mineralization rates over this period also were calculated. We used a $t$ test to compare cumulative amounts of total inorganic $\mathrm{N}$ and net rates of $\mathrm{N}$ mineralization (based on $8 \mathrm{mo}$ in 1997-1998, or 7 mo in 1998-1999) between treatments.

\section{Other soil nutrients}

To determine if biomass removal influenced other soil attributes besides nitrogen, we had one soil sample from each plot analyzed for different soil fractions of $\mathrm{Ca}, \mathrm{Mg}, \mathrm{Mn}, \mathrm{K}$, and P on 13 March 1998 at the University of California-Davis, Division of Agriculture and Natural Resources (DANR) laboratory. Samples were taken between 5 and $10 \mathrm{~cm}$ below the soil surface, and dried for $2 \mathrm{~d}$ at $50^{\circ} \mathrm{C}$ prior to analysis. Amounts of soluble $\mathrm{Ca}, \mathrm{Mg}$, and $\mathrm{K}$ in saturated paste were determined by inductively coupled plasmic atomic emission spectrometry (Lanyon and Heald 1982). Mn was extracted from soil using DTPA; subsequent determination of concentration was made by atomic absorption spectrometry. Exchangeable $\mathrm{Ca}, \mathrm{Mg}$, and $\mathrm{K}$ were determined by first extracting ions in $1 \mathrm{~mol} / \mathrm{L}$ ammonium acetate ( $\mathrm{pH} 7.0$ ), and subsequently determining concentrations by atomic absorption/emission spectrometry. Phosphorus was measured as extractable phosphate using dilute acid-fluoride extractant (Horneck et al. 1989). We compared nutrient concentrations between treated and control plots using separate $t$ tests with Bonferroni adjustment (see Results).

\section{Nitrogen retention}

In August 1997 we installed lysimeters in the center of all plots (Fig. 1), as well as in nearby areas that were historically free from lupine. Our goal was to determine how mowing and the concomitant changes in plant assemblages (see Results) affect amounts of $\mathrm{N}$ leached from sandy soils during winter. Lysimeters were constructed by gluing a $24.5 \mathrm{~cm}$ diameter plastic funnel on the top of a 2-L Nalgene bottle. Small pillows of sand (sterilized play sand enclosed in spun polyester fabric) were placed in each funnel to prevent soil from falling into the lysimeter bottle. The body of each lysimeter bottle had two flexible tubes made of braided polyvinyl chloride (PVC; $1.09 \mathrm{~cm}$ outer diameter) extending from it; one tube functioned as a "breather hole" and the other was used to extract leachate from the bottle. Both braided PVC tubes were long enough to extend above the ground after the lysimeter was buried. Lysimeters were installed so that the top of the lysimeter funnel was $30 \mathrm{~cm}$ below the soil surface. These lysimeters were passive; they had to be pumped dry after every large rain event so they would not overfill with leachate. Since this proved impractical after 1 yr of operation, on 29 September 1998 we replaced 
these lysimeters with suction lysimeters (SoilMoisture Equipment Corporation, Santa Barbara, California, USA). Suction lysimeters only collect leachate after they are evacuated of air. Lysimeters were installed by first using a $5.08 \mathrm{~cm}$ diameter soil core to create a 55 $\mathrm{cm}$ deep bore hole. A small quantity of crushed 200mesh pure silica sand was added to each bore hole and the lysimeter was placed in the cored hole. Another layer of silica sand, $\sim 15 \mathrm{~cm}$ deep, was added after the lysimeter was inserted in the ground. Soil was placed around the lysimeter and tapped to fill in air spaces, ensuring that surface water channels were absent between the soil and the body of the lysimeter. Installed lysimeters extended above the ground $\sim 5 \mathrm{~cm}$.

Starting on 18 November 1998, we sampled leachate in lysimeters after major rain events, which were approximately every 2 wk. During both 1997-1998 and 1998-1999, leachate was pumped from lysimeters into plastic scintillation vials and immediately frozen. Samples were later defrosted and analyzed colorimetrically for $\mathrm{NH}_{4}{ }^{+}$and $\mathrm{NO}_{3}{ }^{-}$, using a Technicon auto analyzer (Technicon, Tarrytown, New York, USA).

We used two separate repeated-measures ANOVAs (on transformed data; transformation $=\ln [1+x]$ ) to compare the concentration of $\mathrm{N}$ in leachate in multiple samples taken from mowed and control sites in 19971998 and 1998-1999, respectively. In 1998-1999 we calculated the amount of $\mathrm{N}$ leached on a grams per meter squared basis. We did this by multiplying the amount of total $\mathrm{N}$ in leachate samples by the cumulative amount of rainfall between sampling periods. Rainfall data were obtained from unpublished archived data collected by the University of California's Bodega Marine Laboratory. We then calculated the cumulative amount of $\mathrm{N}$ leached (on a grams per meter squared basis) for the season by summing all values across the entire season. We used a one-way ANOVA to test for differences in the cumulative amounts of $\mathrm{N}$ leached between control, mowed, and native prairie sites.

Preliminary data from previous years indicated that significantly more $\mathrm{N}$ leached from control plots than from mowed plots. To determine if this might be because of differences in the phenology of plant growth (and hence $\mathrm{N}$ uptake) in the different plots, we took biomass samples in late fall and again in midwinter in mowed and control plots. On 11 November 1998, we sampled all aboveground biomass in $25 \times 30 \mathrm{~cm}$ subplots placed randomly in mowed and control plots. On 26 February 1999, we again took aboveground biomass samples in $20 \times 20 \mathrm{~cm}$ plots placed randomly in mowed, control, and lupine-free sites. Biomass samples were bagged, dried at $60^{\circ} \mathrm{C}$ for $2 \mathrm{~d}$, and weighed. Separate $t$ tests were used to compare the aboveground biomass in mowed and control plots in late fall, and again in early winter.

\section{RESULTS}

Plant biomass, species composition, and $N$ in vegetation

Although both grasses and forbs initially colonized the bare, N-rich soil after lupine died in 1992, weedy
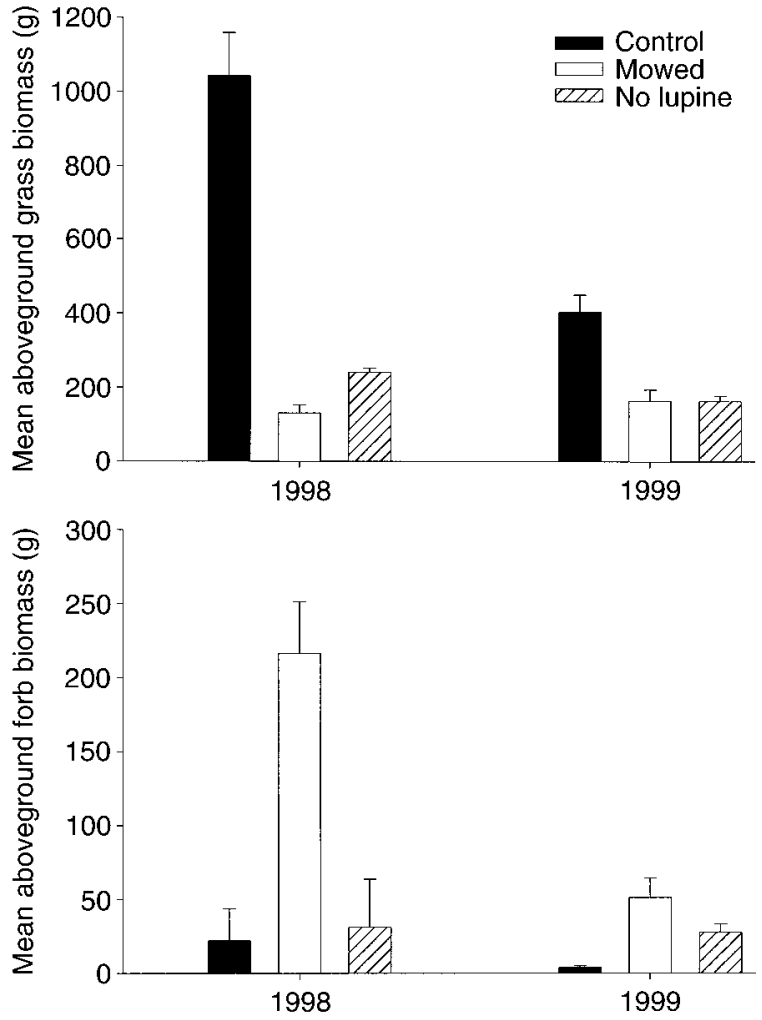

FIG. 2. Mean (+1 SE) aboveground grass (top panel) and forb (bottom panel) biomass (in $\mathrm{g}$ dry mass $/ \mathrm{m}^{2}$ ), in control and mowed plots as well as in low-N grass sites composed of mostly native species, in 1998 and 1999.

introduced grasses, principally Bromus diandrus, Lolium multiflorum, and Vulpia bromoides, quickly dominated control plots. In 1998, these species made up $98 \%$ of the aboveground biomass, and total aboveground biomass in these plots was over twice that in plots that had been mowed (Fig. 2). In 1999 there was less rainfall than in 1998 (annual rainfall from October to April was $167.3 \mathrm{~cm}$ in 1998 compared to $109.7 \mathrm{~cm}$ in 1999), and aboveground grass production in control plots was significantly reduced, compared to 1998 (repeated-measures ANOVA with significant differences between years, $\left.F_{1,10}=41.3, P<0.0001\right)$. Despite this decrease, there was again significantly more aboveground biomass in control vs. mowed plots (Fig. 2; rm ANOVA, $\left.F_{1,10}=48.1, P<0.0001\right)$.

Because of the dominance of exotic grasses, control plots had very low species richness (Fig. 3). In contrast, species richness in mowed plots was higher than that in control plots (rm ANOVA, $F_{1,10}=21.9, P<0.001$ ), primarily because of the increased contribution of perennial forbs. In 1998, low-lying forbs comprised $60 \%$ of the mean aboveground biomass in mowed plots; native species comprised $29 \%$ of the total forb species richness in these plots. In 1999, forbs comprised $27 \%$ of the total aboveground biomass in mowed plots $(44 \%$ of this forb biomass, on average, was composed of 

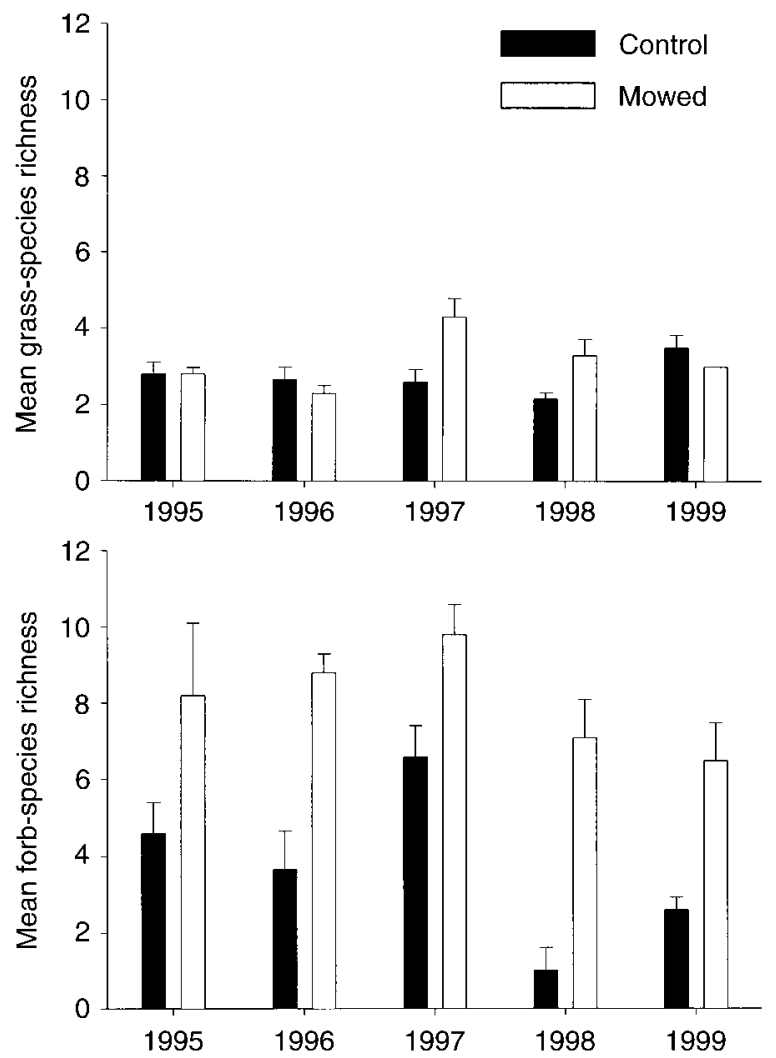

FIG. 3. Changes in mean values ( $+1 \mathrm{SE})$ of the total number of species of grasses (top panel) and forbs (bottom panel), in control and mowed plots, from 1995 to 1999.

natives), a significant decrease compared to corresponding values for 1998 (mean dry biomass of perennials was 216.5 and $51.4 \mathrm{~g} / \mathrm{m}^{2}$ in 1998 and 1999 , respectively; significant effect of year in rm ANOVA, $\left.F_{1,10}=63.7, P<0.0001\right)$. However, across both years, the belowground biomass of vegetation was significantly greater in mowed vs. control plots (Fig. 4; rm ANOVA, $\left.F_{1,10}=11.6, P<0.0067\right)$.

In 1998, the nitrogen content of grasses and forbs was similar in control and mowed plots. Grasses and forbs contained an average of $1.8 \%$ and $1.91 \% \mathrm{~N}$, respectively. The belowground forb biomass contained $1.1 \% \mathrm{~N}$ on average. In 1999, the nitrogen content of grasses averaged $1.5 \%$ and $1.4 \%$ in control and mowed plots, respectively, a nonsignificant difference $(\mathrm{df}=10$, $t=0.86, P=0.41)$. The belowground forb biomass contained, on average, $0.93 \% \mathrm{~N}$.

\section{Seed addition}

Supplementing subplots within mowed plots with both seeds of Bromus diandrus and litter resulted in significantly more $B$. diandrus recruitment (as measured by flowering culms) compared to that in subplots to which neither seeds nor litter was added (ANOVA, $\left.F_{2,15}=4.88, P<0.024\right)$. There were $98.1 \pm 18.4$ flowering culms of $B$. diandrus (mean $\pm 1 \mathrm{SE}$ ) in sub- plots where seeds and litter were added, compared to $69.7 \pm 10.3$ culms in subplots that received only seeds, and $39.8 \pm 9.1$ culms in control subplots. The difference in the number of flowering shoots between plots that received seed addition only and the control subplots was not significant (Tukey post hoc comparison, $P=0.28)$.

\section{Total soil $N$ and $C$}

Mowing had little effect on total soil nitrogen $(\mathrm{df}=$ $10, t=-0.061$ and $-0.58, P>0.5$ for 1998 and 1999, respectively). Total soil nitrogen in control plots averaged 270 and $250 \mathrm{~g} / \mathrm{m}^{2}$ in 1998 and 1999, respectively; total soil nitrogen in mowed plots averaged 270 and $280 \mathrm{~g} / \mathrm{m}^{2}$ in 1998 and 1999, respectively. Similarly, in both 1998 and 1999 total soil carbon was not significantly different between mowed and control plots $(t=-0.58$ and $-1.0, P>0.34$ in 1998 and 1999, respectively). Total soil carbon in control plots averaged 4170 and $4550 \mathrm{~g} / \mathrm{m}^{2}$ in 1998 and 1999, respectively, and total soil carbon in mowed plots averaged 3420 and $4050 \mathrm{~g} / \mathrm{m}^{2}$, respectively.

\section{Exchangeable levels of inorganic soil nitrogen and net rates of nitrogen mineralization}

Mowing resulted in an estimated removal of between 2.43 and $6.33 \mathrm{~g} \mathrm{~N} / \mathrm{m}^{2}$ from plots annually, and a mean cumulative total removal of $22.0 \mathrm{~g} \mathrm{~N} / \mathrm{m}^{2}$ over the $5-\mathrm{yr}$ experiment (Table 1). Despite this, cumulative amounts of exchangeable soil inorganic $\mathrm{N}$ (summed across 8 mo) were not significantly different between mowed and control plots in 1997-1998 $(\mathrm{df}=10, t=0.74, P$ $=0.48)$ or in 1998-1999 (df $=10, t=-1.29, P=$ 0.23 ). The mean cumulative total amount of exchangeable $\mathrm{N}\left(\mathrm{NH}_{4}{ }^{+}\right.$and $\left.\mathrm{NO}_{3}{ }^{-}\right)$was 106 and $40 \mu \mathrm{g} / \mathrm{g}$ dry mass of soil in control plots and 96 and $46 \mu \mathrm{g} / \mathrm{g}$ dry mass of soil in mowed plots in 1997-1998 and 1998-1999, respectively.

Rates of net nitrogen mineralization were also not significantly different between control and mowed plots in $1997-1998$ (df $=10, t=-0.28, P=0.78$ ) or

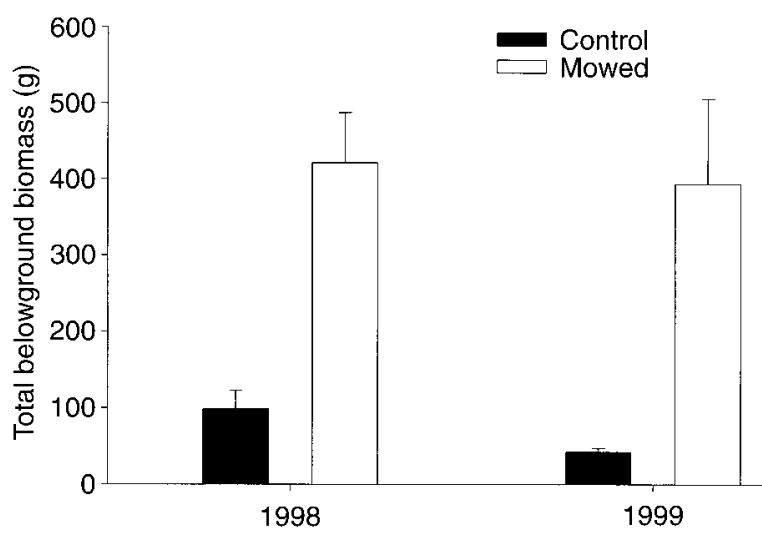

FIG. 4. Mean (+1 SE) belowground biomass (in g dry mass $/ \mathrm{m}^{2}$ ), in control and mowed plots, in 1998 and 1999. 
TABLE 1. Annual changes in aboveground biomass in control and mowed plots, and amounts of nitrogen $(\mathrm{N})$ removed in mowed vegetation.

\begin{tabular}{lrrrrr}
\hline \hline \multicolumn{1}{c}{ Measure } & 1994 & 1995 & 1996 & 1997 & 1998 \\
\hline Biomass in control plots $\left(\mathrm{g} / \mathrm{m}^{2}\right)$ & 489 & 687 & 689 & 295 & 1080 \\
Biomass removed from mowed plots $\left(\mathrm{g} / \mathrm{m}^{2}\right)$ & 334 & 327 & 474 & 190 & 347 \\
N content of biomass $(\%$ dry mass) & 1.1 & 1.3 & 1.1 & 1.3 & 1.8 \\
Total N removed $\left(\mathrm{g} / \mathrm{m}^{2}\right)$ & 3.8 & 4.4 & 5.1 & 2.4 & 6.3 \\
\hline
\end{tabular}

in $1998-1999(\mathrm{df}=10, t=0.89, P=0.39)$. In both years, mineralization rates peaked in midwinter (Fig. 5 ), a trend detected at our site in previous years (Maron and Jefferies 1999).

\section{$N$ limitation in mowed plots}

Vegetation in plots that had been mowed for $4 \mathrm{yr}$ was not nitrogen-limited. Addition of urea to subplots within mowed plots had no significant effect on total aboveground plant biomass ( $\mathrm{df}=10, t=0.935, P=$ $0.37)$. The mean biomass of vegetation in urea addition subplots was $40.0 \pm 5.16 \mathrm{~g}$ dry mass (mean $\pm 1 \mathrm{SE}$ ) compared to $33.1 \pm 5.28 \mathrm{~g}$ in control subplots. As well, mowing and biomass removal for $4 \mathrm{yr}$ had no effect on soluble and exchangeable amounts of $\mathrm{Ca}, \mathrm{Mg}, \mathrm{K}$, or on exchangeable levels of $\mathrm{P}$, or total amounts of $\mathrm{Mn}$ in soils (separate $t$ tests, $P>0.1$; Table 2).

\section{Nitrogen retention}

The highest concentrations of $\mathrm{N}$ in leachate were detected in winter, when net rates of mineralization were highest (Fig. 6). In both 1997-1998 and 19981999, samples of leachate from control plots contained significantly greater concentrations of inorganic nitrogen $\left(\mathrm{NH}_{3}{ }^{+}\right.$and $\left.\mathrm{NO}_{3}{ }^{-}\right)$compared to those taken from mowed plots (repeated-measures ANOVA, $F_{2,7}=16.6$, $P<0.005$ for 1997-1998, and rm ANOVA, $F_{1,7}=$ $18.4, P<0.004$ for $1998-1999)$. In 1998-1999, the total amount of nitrogen leached from control plots was $4.8 \pm 1.0 \mathrm{~g} \mathrm{~N} / \mathrm{m}^{2}$, compared to $1.3 \pm 0.14 \mathrm{~g} \mathrm{~N} / \mathrm{m}^{2}$ in mowed plots, and $0.67 \pm 0.32 \mathrm{~g} \mathrm{~N} / \mathrm{m}^{2}$ for native grassland, a significant difference (ANOVA, $F_{2,12}=13.2, P$ $<0.001$, Bonferroni post hoc comparison, $P<0.001$ between control and mowed plots).

\section{DISCUSSION}

\section{Species composition and the effects of seed addition}

Mowing had a rapid effect on species richness that was detected a year after the initial mowing event. Thereafter, there was little overall change in species richness or in turnover of species in mowed plots. The major change was an approximate doubling of the number of forb species present in mowed plots compared with corresponding values in control plots. As well, during the 5-yr experiment, the relative abundances of the different species of forbs changed, mostly as a result of clonal growth. Initially, removal of the standing crop dominated by grass biomass and the associated thick litter layer changed conditions in these plots, and allowed the successful early establishment of annual forb species, particularly two species of Lasthenia ( $L$. minor and L. californica) and a variety of native clovers (Trifolium) that germinated from the seed bank. However, through time, two species of perennial forbs, the native Achillea millefolium and the introduced Rumex acetosella, increased greatly in abundance, although there was considerable plot-to-plot variability in their abundances. Annual variability in weather patterns also influenced species abundances and standing crop. Rainfall amounts were extremely high during the El Niño winter-spring of 1998, which led to over twice the grass biomass in control plots and over twice the perennial forb biomass in mowed plots in 1998, compared to corresponding values in 1999 or in other years (Fig. 2; J. L. Maron and R. L. Jefferies, unpublished data). In contrast to forbs, grasses showed little change in species composition throughout the experiment. At the end of the experiment in 1999, the two most abundant grasses in both mowed and control plots were Bromus diandrus and Vulpia bromoides. Yet, although mowed and control plots contained identical grass species, the portion of the total plant biomass that was composed of these species was dramatically lower in mowed vs. control plots.

Although lupines established and then died in control plots, this seemed to have little effect on the species composition of plots. The species richness and composition within additional plots that we established in 1993 (unmowed but kept free of lupine for $5 \mathrm{yr}$ ), did not differ significantly from the composition of control plots where lupine established and then died (J. L. Maron and R. L. Jefferies, unpublished data). The immediate effects of mowing on vegetation was likely the result of altering the germination environment, which allowed several annual native clovers, as well as some perennials, to germinate from the seed bank. Yet, despite years of mowing and the presence of bare soil patches in mowed plots, there was no cumulative increase in total or native species richness in plots, suggesting that species were dispersal limited. Mowing also contributed to dispersal limitation by removing the seeds of many species that normally germinated from the seed bank. Dispersal limitation has been shown to be an important determinant of species richness in other grassland systems (Cavers and Harper 1967, Grubb 1977, Tilman 1997), and may constrain the success of attempts to reestablish natives solely by reducing soil nitrogen (Marrs 1993). 

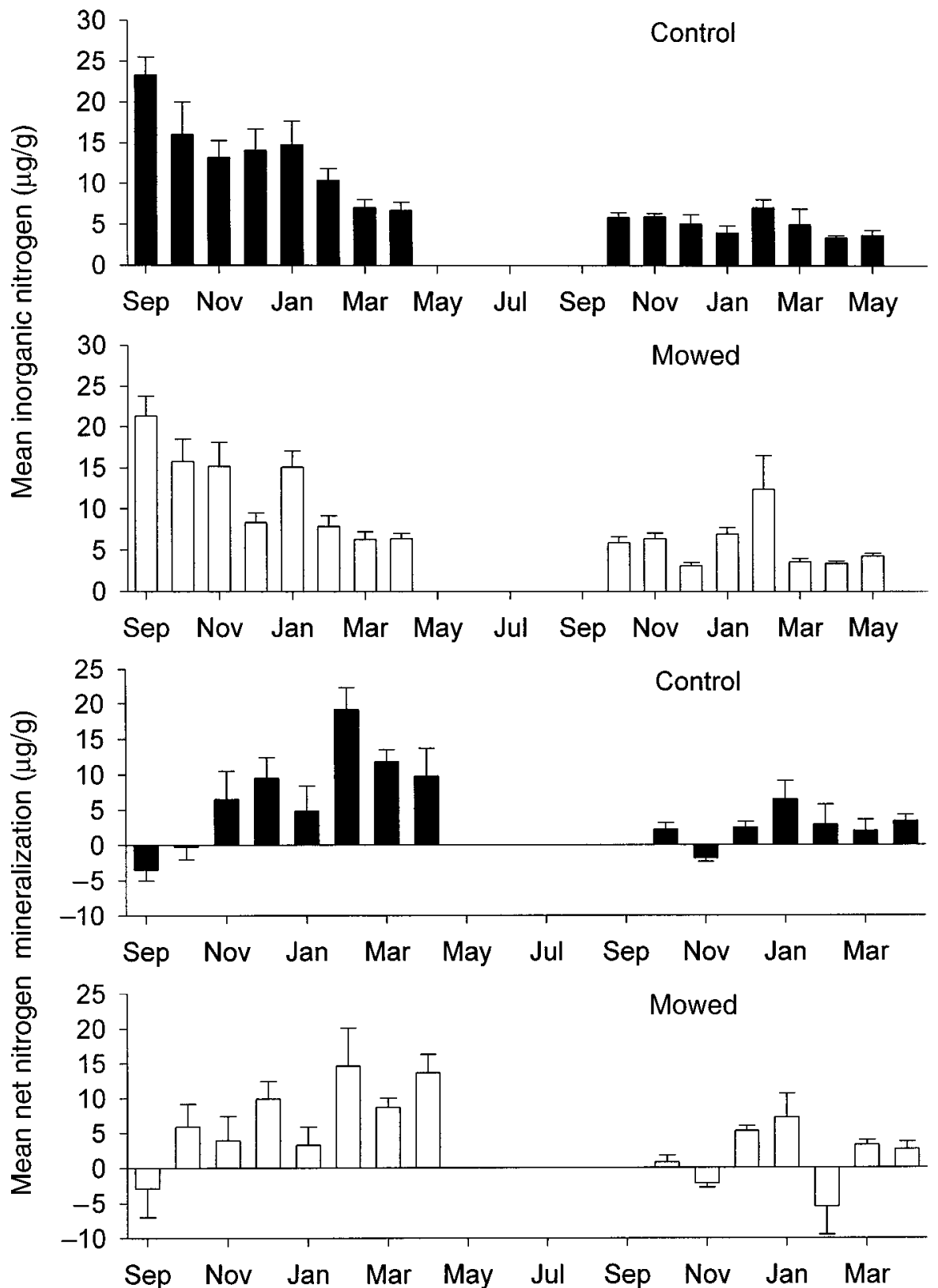

FIG. 5. Mean (+1 SE) exchangeable inorganic nitrogen $\left(\mathrm{NH}_{4}{ }^{+}\right.$and $\mathrm{NO}_{3}^{-}$; top two panels) and mean (+1 SE) net nitrogen mineralization in soil (bottom two panels), in control and mowed plots.

TABLE 2. Concentration of soil nutrients (mean $\pm 1 \mathrm{SE})$ in samples from mowed and control plots $(n=6$; all values in $\mathrm{mg} / \mathrm{kg}$ ).

\begin{tabular}{lcr}
\hline \hline \multicolumn{1}{c}{ Nutrient } & Mowed plots & Control plots \\
\hline Soluble calcium & $20.3 \pm 1.4$ & $19.6 \pm 1.6$ \\
Soluble magnesium & $24.0 \pm 1.60$ & $26.3 \pm 2.30$ \\
Soluble potassium & $5.3 \pm 0.86$ & $6.1 \pm 0.91$ \\
Extractable manganese & $30.1 \pm 3.60$ & $22.0 \pm 2.70$ \\
Bray phosphorus & $51.2 \pm 5.30$ & $60.7 \pm 8.30$ \\
Exchangeable calcium & $880.0 \pm 66.0$ & $873 \pm 45.0$ \\
Exchangeable magnesium & $437 \pm 360$ & $493 \pm 24.0$ \\
Exchangeable potassium & $69.3 \pm 6.90$ & $82.3 \pm 7.00$ \\
\hline
\end{tabular}

In contrast, mowing greatly reduced the abundance of the exotic grasses Bromus diandrus and Lolium multiflorum. In spite of a large seed production, dispersal from surrounding areas was ineffective and these annual grasses failed to establish at high densities in mowed plots where in situ seed production was removed each year. When seeds of $B$. diandrus were added to mowed plots in the presence and absence of litter, there was an increasing trend in the density of flowering culms from plots where no addition of seed was made, to plots where both seed and litter were added. These results suggest that biomass removal of both seed and 

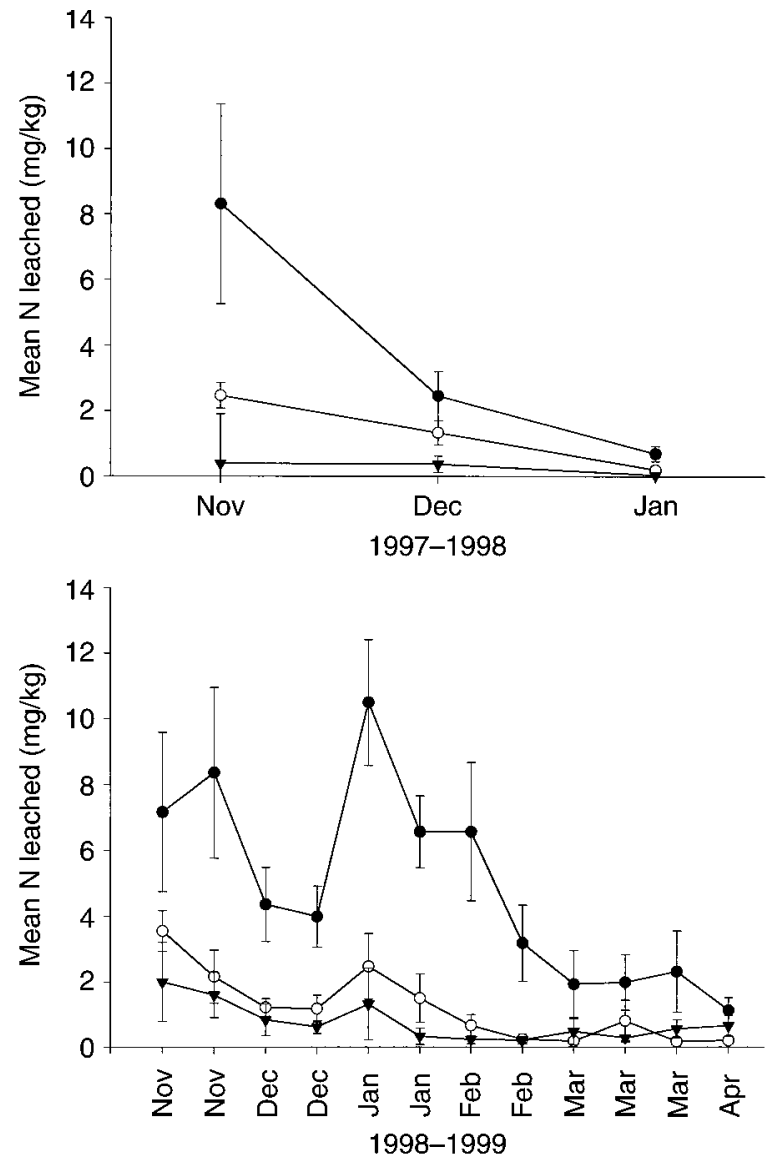

FIG. 6. Mean ( $\pm 1 \mathrm{SE})$ concentrations of nitrate nitrogen in water collected in soil lysimeters in winter of 1997-1998 (top panel), and 1998-1999 (bottom panel), in control (solid circles) and mowed (open circles) plots, as well as in low-N grassland sites composed of mostly native species (closed triangles); $(n=6)$.

litter adversely affected recruitment of exotic annual grasses the following season. At the same time, litter removal likely increased overall species richness by facilitating the establishment of forbs (Carson and Peterson 1990, Foster and Gross 1998). Thus, while a lack of native propagules limited the ultimate effectiveness of mowing in reestablishing a more speciesrich native community, mowing also led to the removal of exotic grass propagules, causing reductions in exotic grass biomass in mowed plots.

\section{Soil nitrogen characteristics}

Collectively, the results indicate that after $5 \mathrm{yr}$ of mowing and biomass removal, and the presence of a different species assemblage compared to that of control plots, the overall characteristics of the soil-nitrogen pool changed little in response to mowing. During the 5 -yr experiment, an estimated $22.0 \mathrm{~g} / \mathrm{m}^{2}$ of $\mathrm{N}$ were removed in plant biomass from mowed plots. This represented $\sim 9 \%$, on average, of the total soil-nitrogen pool in 1999. This reduction was insufficient to lead to nitrogen limitation of plant growth based on the lack of response of plants to the addition of urea. However, during the 5-yr experiment, the soil-nitrogen pool in all plots declined. This likely resulted from the absence of lupine, even from control plots in most years. Soil from under mature lupine bushes can have a total nitrogen content in excess of $500 \mathrm{~g} / \mathrm{m}^{2}$, although values between 300 and $450 \mathrm{~g} / \mathrm{m}^{2}$ are more usual. By the end of the experiment, total soil nitrogen had fallen to an average of $265 \mathrm{~g} / \mathrm{m}^{2}$ across both control and treated plots. In spite of this, the $\mathrm{C} / \mathrm{N}$ ratio of the soil organic matter was unchanged at between 15 and 17 over the 5 -yr experiment. This value was similar to that of live lupine leaves and fresh leaf litter. In addition, the ratio of the cumulative net amount of nitrogen mineralized to the total amount of nitrogen in the soil was similar between treated and control plots, and between different sites (experimental and mostly native prairie grassland sites). The ratio varied between 0.015 and 0.020 . The results suggest that soil organic matter is still largely influenced by earlier and current (over 5 yr) inputs from lupine plants, and that this accounts for the scaling of the soil-nitrogen pool at sites and the similar mineralization/pool ratios. Given the similarities in soil $\mathrm{N}$ status between mowed and control plots, it is not surprising that the nitrogen content of the grasses and forbs in these plots was also the same. Significantly, the C/ $\mathrm{N}$ ratio of the $\mathrm{C}_{3}$ grasses and $\mathrm{C}_{3}$ forbs was above 30 ; hence, their influence on short-term soil nitrogen dynamics appears to be small. In isolation, the similarities in soil and plant nitrogen status between plots might lead one to believe that the differences in species composition between our treatments had no effect on nitrogen cycling. Lysimeter data, however, revealed that this is not the case.

\section{Nitrogen retention}

Although mowing and biomass removal had little influence on the total soil-nitrogen pool, it had substantial effects on the fate of nitrate-nitrogen. In control plots, large amounts of nitrate ions were leached from the upper soil layers relative to amounts leached from mowed plots and from nearby plots within native grasslands. Much of this nitrate was lost from control plots in fall and early winter. At this time, the onset of winter rains stimulates microbial activity, increasing rates of net mineralization of soil nitrogen and exchangeable levels of inorganic nitrogen. However, in late fall and early winter, soils in control plots are effectively fallow, because exotic annual grasses have not attained appreciable biomass. In contrast, in mostly native grasslands and in mowed plots, perennial plants, some with deep and robust root systems, appear to trap nitrate, thereby conserving the supply of nitrogen at the local level.

The results and conclusions are similar to those of agricultural studies indicating that when a grassland ley is broken in autumn, large losses of nitrate occur 
as a result of soil leaching because mineralization of nitrogen at this stage far outstrips crop uptake (Powlson 1994). In related studies, Addiscott et a1. (1991) reported large nitrate losses from fallow fields after the harvest in autumn when mineralization rates were high, although there was no nitrogen demand from crops at that time.

\section{Ecosystem function}

How might $\mathrm{N}$ enrichment, biological invasions, and loss of species diversity influence ecosystem functioning? This is a particularly important question for Californian grasslands, where exotic N-fixing shrubs increasingly threaten grassland systems (Randall et al. 1998). Wedin and Tilman (1996) found that experimental nitrogen enrichment of N-limited grasslands led to changes in abundance of plant functional groups $\left(\mathrm{C}_{4}\right.$ to $\mathrm{C}_{3}$ plants), which increased rates of $\mathrm{N}$ mineralization and altered the soil-carbon budget and the ability of the soil to retain $\mathrm{N}$. In their study, as in many similar studies, nitrogen loss from leaching was estimated indirectly from mass balance equations. Our results indicate that the conversion of low soil-nitrogen grasslands dominated by perennials, to enriched systems dominated by annual grasses, also can affect ecosystem functioning. In particular, direct measurements of soil$\mathrm{N}$ loss indicate that in areas dominated by annual grasses, soils become "leaky" to nitrogen, which results in a large loss of nitrate in fall. This may be a particularly important, but specific, feature of mediterranean systems dominated by exotic annuals, since the timing of early rainfall corresponds to a time when little annual vegetation is present. Later in spring, however, leaching loss of soil $\mathrm{N}$ is reduced because of the high demand for $\mathrm{N}$ by annual grasses, whose aboveground biomass can contain up to $19.1 \mathrm{~g} \mathrm{~N} / \mathrm{m}^{2}$. In contrast, in communities that are dominated by mostly native perennials, the soils are substantially less N "leaky," particularly in fall and early winter. The belowground biomass effectively takes up nitrate that is available in soil in late fall. Joffre's (1990) study in southwestern Spain similarly showed greater rates of $\mathrm{N}$ leaching in areas dominated by annual grasses, compared to areas supporting perennial grasses. In successional tropical forest systems, Ewel et al. (1991) found that more nitrogen was leached from annual crop assemblages compared to diverse assemblages of native perennials. As in our experiments, both the increased root biomass of perennials compared with that of annuals, and the ability of perennials to take up soil $\mathrm{N}$ at times of the year when annuals were inactive, accounted for the differences in rates of $\mathrm{N}$ leaching from soils. However, in another study, when plant functional group diversity was experimentally manipulated, soils with different functional groups present failed to show different rates of $\mathrm{N}$ leaching compared to soils with less diverse plant assemblages (Hooper and Vitousek 1998).

\section{Implications for management}

The results of our study imply that caution is needed in the use of mowing as a management tool for lowering the amount of soil $\mathrm{N}$ in annual grasslands at BMR. Mowing can result in an almost immediate increase in species richness, and a reduction in exotic grass biomass, but it increases the relative abundance of perennials, which act to decrease the effectiveness of mowing as a tool to reduce soil $\mathrm{N}$. The rate at which $\mathrm{N}$ is depleted by mowing is balanced almost entirely by the difference in loss of leached nitrogen between control and mowed plots $\left(22-25 \mathrm{~g} / \mathrm{m}^{2}\right.$ for the $5-\mathrm{yr}$ period). Thus, the time required for $50 \%$ depletion of soil nitrogen is likely to be the same in mowed and unmowed plots devoid of lupine: the difference between treatments is reflected in the export route of nitrogen from these plots. Even in the absence of a change in the vegetation, mowing is predicted to take many years to have a demonstrable effect on soil-nitrogen pools. When agricultural fields are left fallow, it takes at least $20 \mathrm{yr}$ for comparable amounts of soil nitrogen (as occurs in these plots at the BMR) to be reduced by $50 \%$ (Addiscott et al. 1991). Conversely, if mowing ceased, it is predicted that the species assemblage would revert to annual grasses within a 5-yr period, and an equivalent length of time would be required to deplete the soil-nitrogen pool by $50 \%$ in the absence of lupine. Yet while mowing may not result in immediate reductions in soil nitrogen, it can reduce the possibility of ground water contamination, and has the potential to lead to an increase in species richness, especially if the dispersal of propagules is not limiting. This points to a larger issue of potentially conflicting goals of restoration. While in many contexts a positive outcome of restoration might be to reduce $\mathrm{N}$ leaching and avoid $\mathrm{N}$ contamination of ground or stream water, in the context of restoring invaded grasslands it is the long-term reduction in soil nitrogen that is desired, since this may ultimately favor native species reestablishment.

\section{ACKNOWLEDGMENTS}

We thank the staff at the Bodega Marine Laboratory, particularly Peter Connors, Victor Chow, and Alex Reich for their help and support of our work. Penny Bateman, Julie Combs, Cheryl Dean, Mary Greaves, Susan Jefferies, Alex Reich, and Jeanne Robertson all greatly helped with fieldwork. Deborah Tam provided her usual expert analyses of soils and plant tissue. Peter Alpert, Anthony Davy, and two anonymous reviewers provided valuable comments on the manuscript. Research was financially supported by NSF grant DEB-9726551 to J. L. Maron, and funding from Natural Sciences and Engineering Research Council of Canada to R. L. Jefferies.

\section{Literature Cited}

Addiscott, T. M., A. P. Whitmore, and D. S. Powlson. 1991. Farming, fertilizers and the nitrate problem. C.A.B. International, Wallingford, UK.

Aerts, R., and F. Berendse. 1988. The effect of increased nutrient availability on vegetation dynamics in wet heathlands. Vegetatio 76:63-69.

Bakker, J. P., and F. Berendse. 1999. Constraints in the res- 
toration of ecological diversity in grassland and heathland communities. Trends in Ecology and Systematics 14:6368.

Bobbink, R. 1991. Effects of nutrient enrichment in Dutch chalk grassland. Journal of Applied Ecology 28:28-41.

Bobbink, R., and J. H. Willems. 1987. Increasing dominance of Brachypodium pinnatum (L.) Beauv. in chalk grasslands: a threat to a species-rich ecosystem. Biological Conservation 40:301-314.

Burke, M. J. W., and J. P. Grime. 1996. An experimental study of plant community invasibility. Ecology 77:776790.

Carson, W. P., and C. J. Peterson. 1990. The role of litter in an old-field community: impact of litter quantity in different seasons on plant species richness and abundance. Oecologia 85:8-13.

Cavers, P. B., and J. L. Harper. 1967. Studies in the dynamics of plant populations. 1. The fate of seed and transplants into various habitats. Journal of Ecology 55:59-71.

Collins, S. L., A. K. Knapp, J. M. Briggs, J. M. Blair, and E. M. Steinauer. 1998. Modulation of diversity of grazing and mowing in native tallgrass prairie. Science 280:745747.

Davidson, E. D. 1975. Demography of Lupinus arboreus at Bodega Head, California. Thesis. University of California, Davis, California, USA.

Ewel, J. J., M. J. Mazzarino, and C. W. Berish. 1991. Tropical soil fertility changes under monocultures and successional communities of different structure. Ecological Applications 1:289-302.

Foster, B. L., and K. L. Gross. 1998. Species richness in a successful grassland: effects of nitrogen enrichment and plant litter. Ecology 79:2593-2602.

Galloway, J. N., H. Levy, and P. S. Kasibhatla. 1994. Year 2020: consequences of population growth and development on deposition of oxidized nitrogen. Ambio 23:120-123.

Grime, J. P. 1979. Plant strategies and vegetation processes. Wiley, Chichester, UK

Grubb, P. J. 1977. The maintenance of species richness in plant communities: the importance of the regeneration niche. Biological Review 52:107-145.

Heady, H. F., T. C. Foin, M. M. Hektner, D. W. Taylor, M. G. Barbour, and W. J. Barry. 1995. Coastal prairie and northern coastal scrub. Pages 733-760 in M. G. Barbour and J. Major, editors. Terrestrial vegetation of California. Special publication number 9. California Native Plant Society, Davis, California, USA.

Hobbs, R. J., and L. F. Huenneke. 1992. Disturbance, diversity, and invasion: implications for conservation. Conservation Biology 6:324-337.

Hooper, D. U., and P. M. Vitousek. 1998. Effects of plant composition and diversity on nutrient cycling. Ecological Monographs 68:121-149.

Horneck, D. A., J. M. Hart, K. Topper, and B. Koespell. 1989. Methods of soil analysis used in the soil testing laboratory at Oregon State University. Agricultural Experiment Station SM 89:4.

Huenneke, L. F., S. P. Hamburg, R. Koide, H. A. Mooney, and P. M. Vitousek. 1990. Effects of soil resources on plant invasion and community structure in Californian serpentine grassland. Ecology 71:478-491.

Jenkinson, D. S., and A. E. Johnston. 1977. Soil organic matter in the Hoosefield continuous barley experiment. Pages 87-101 in Rothhamsted Experimental Station report for 1976. Part 2. Rothhamsted Experimental Station, Harpenden, Hertfordshire, UK.

Joffre, R. 1990. Plant and soil nitrogen dynamics in Mediterranean grasslands: a comparison of annual and perennial grasses. Oecologia 85:142-149.

Johnston, A. E., and P. R. Poulton. 1977. Yields on the ex- haustion land and changes in the NPK contents of the soils due to cropping and manuring, 1852-1975. Pages 53-85 in Rothhamsted Experimental Station report for 1976. Part 2. Rothhamsted Experimental Station, Harpenden, Hertfordshire, UK.

Lanyon, L. E., and W. R. Heald. 1982. Magnesium, calcium, strontium, barium. Pages 247-262 in Methods of soil analysis: part 2. Chemical and microbiological properties. Monograph Number 9. American Society of Agronomy, Madison, Wisconsin, USA.

Maron, J. L. 1998. Insect herbivory above- and belowground: individual and joint effects on plant fitness. Ecology 79: $1281-1293$

Maron, J. L., and P. G. Connors. 1996. A native nitrogenfixing shrub facilitates weed invasion. Oecologia 105:302312 .

Maron, J. L., S. P. Harrison, and M. E. Greaves. 2001. Origin of an insect outbreak: escape in space or time from natural enemies? Oecologia 126:595-602.

Maron, J. L., and R. L. Jefferies. 1999. Bush lupine mortality, altered resource availability, and alternative vegetation states. Ecology 80:443-454.

Marrs, R. H. 1993. Soil fertility and nature conservation in Europe: theoretical considerations and practical management solutions. Advances in Ecological Research 24:241300 .

Milchunas, D. G., and W. K. Lauenroth. 1995. Inertia in plant community structure: state changes after cessation of nutrient-enrichment stress. Ecological Applications 5:452458.

Powlson, D. S. 1994. Quantification of nutrient cycles using long-term experiments. Pages 97-116 in R. A. Leigh and A. E. Johnston, editors. Long-term experiments in agricultural and ecological sciences. CAB International, Wallingford, UK

Randall, J. M., M. Rejmánek, and J. C. Hunter. 1998. Characteristics of the exotic flora of California. Fremontia 26: 3-12.

Rizand, A., R. H. Marrs, M. W. Gough, and T. C. E. Wells. 1989. Long-term effects of various conservation management treatments on selected soil properties of chalk grassland. Biological Conservation 49:105-112.

Stock, W. D., and N. Allsopp. 1992. Functional perspective of ecosystems. Pages 241-259 in R. M. Cowling, editor. The ecology of fynbos: nutrients, fire and diversity. Oxford University Press, Cape Town, South Africa.

Stock, W. D., K. T. Wienand, and A. C. Baker. 1995. Impacts of invading $\mathrm{N}_{2}$-fixing Acacia species on patterns of nutrient cycling in two Cape ecosystems: evidence from soil incubation studies and ${ }^{15} \mathrm{~N}$ natural abundance values. Oecologia 101:375-382.

Stohlgren, T. J., D. Binkley, G. W. Chong, M. A. Kalkhan, L. D. Schell, K. A. Bull, Y. Otsuki, G. Newman, M. Bashkin, and Y. Son. 1999. Exotic plant species invade hot spots of native plant diversity. Ecological Monographs 69:2546.

Strong, D. R., J. L. Maron, P. G. Connors, A. V. Whipple, S. Harrison, and R. L. Jefferies. 1995. High mortality, fluctuation in numbers, and heavy subterranean insect herbivory in bush lupine, Lupinus arboreus. Oecologia 104:8592.

SYSTAT. 1998. SYSTAT for Windows. Version 8.0. SPSS, Chicago, Illinois, USA.

Tilman, D. 1988. Plant strategies and the dynamics and structure of plant communities. Princeton University Press, Princeton, New Jersey, USA.

Tilman, D. 1997. Community invasibility, recruitment limitation, and grassland biodiversity. Ecology 78:81-92.

Vermeer, J. G., and F. Berendse. 1983. The relationship between nutrient availability, shoot biomass, and species- 
richness in grassland and wetland communities. Vegetatio 53:121-126.

Vinton, M. A., and I. C. Burke. 1997. Contingent effects of plant species on soils along a regional moisture gradient in the Great Plains. Oecologia 110:393-402.

Vitousek, P. M., J. D. Aber, R. W. Howarth, G. E. Likens, P. A. Matson, D. W. Schindler, W. H. Schlesinger, and D. G. Tilman. 1997. Human alteration of the global nitrogen cycle: sources and consequences. Ecological Applications 7: 737-750.

Vitousek, P. M., and L. R. Walker. 1989. Biological invasion by Myrica faya in Hawaii: plant demography, nitrogen fixation, and ecosystem effects. Ecological Monographs 59: $247-265$
Wedin, D. A., and D. Tilman. 1990. Species effects on nitrogen cycling: a test with perennial grasses. Oecologia 84: 433-441.

Wedin, D. A., and D. Tilman. 1996. Influence of nitrogen loading and species composition on the carbon balance of grasslands. Science 274:1720-1723.

Wilson, E. J., T. C. E. Wells, and T. H. Sparks. 1995. Are calcareous grasslands in the UK under threat from nitrogen deposition? An experimental determination of a critical load. Journal of Ecology 83:823-832.

Witkowski, E. T. F. 1991. Effects of invasive alien Acacias on nutrient cycling in the coastal lowlands of the Cape Fynbos. Journal of Applied Ecology 28:1-15. 